\title{
Desain Penguatan Pembelajaran Bahasa Arab di MI NU Miftahul Ulum Loram Kulon Jati Kudus
}

\author{
Achmad Zuhri \\ IAIN Kudus, Indonesia \\ achmadzuhri@iainkudus.ac.id
}

Khusnul Aflah

MI NU Miftahul Ulum, Jati, Kudus, Indonesia afwamultitech@yahoo.com

\begin{abstract}
This study aims to describe the design of strengthening the learning of Arabic in MI NUMiftahul Ulum Loram Kulon Jati Kudus, one of the Islamic elementary schoolthat integrates the Ministry of Religion curriculum with the local curriculum, and is the only Islamic elementary school that still maintains salafi subjects. The researcher uses a qualitative case study type method, which is one type of research in which the researcher explores in depth the research object. Data collected by interview, observation and documentation, then the data are analyzed by means of reduction, presentation of data, drawing conclusions and verification. The results showed that the design of strengthening learning Arabic by collaborating with local subjects such as BTA in the lower classes, nahwu and shorof in the upper classes. With such a model students will easily understand Arabic material, and be able to analyze and present it with appropriate language rules.
\end{abstract}

Keyword: Design of strengthening, learning of Arabic, and MI NUMiftahul Ulum Kudus. 


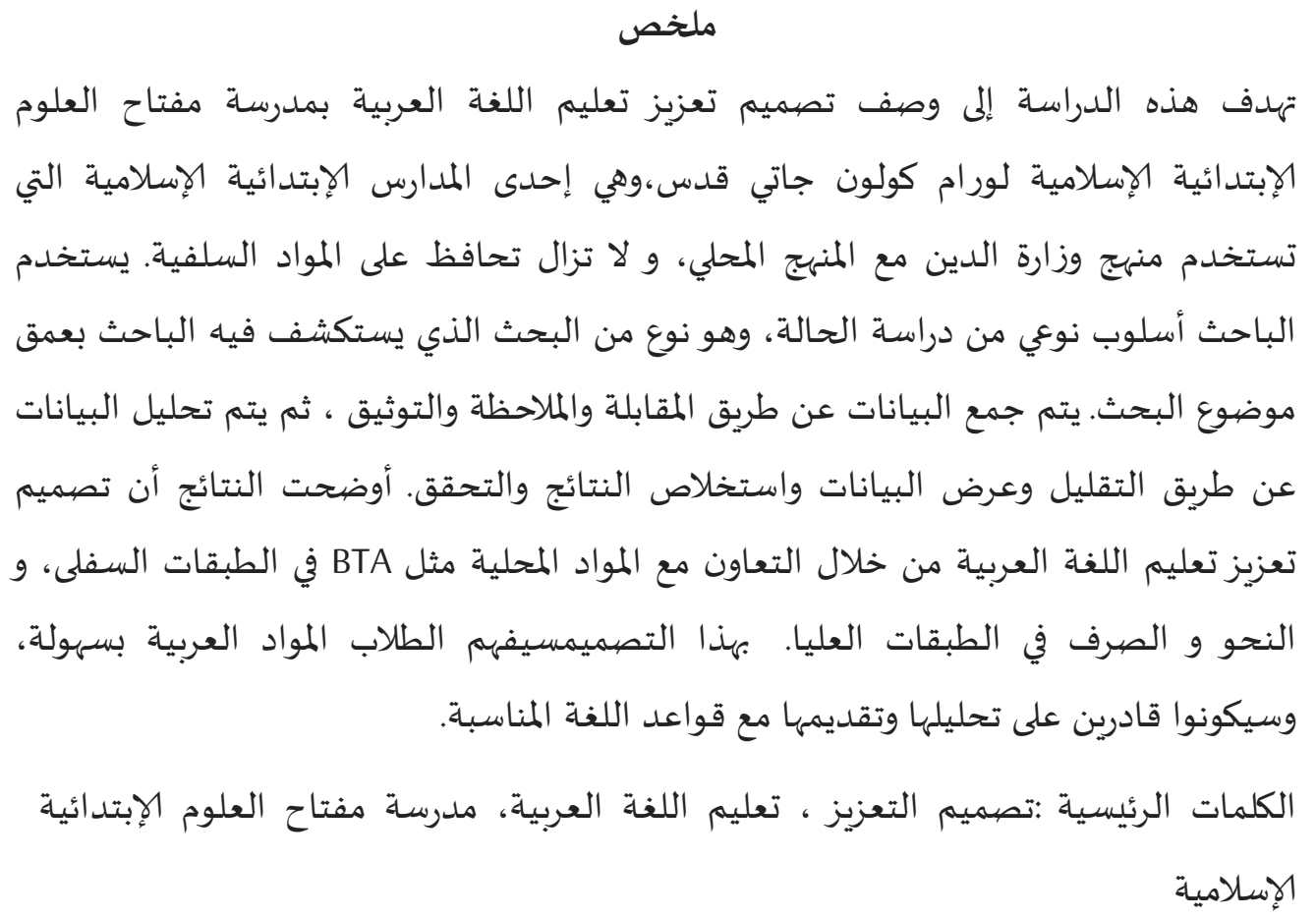

Abstrak

Kajian ini bertujuan untuk mrndeskripsikan desain penguatan pembelajaran bahasa Arab di MI NU Miftahul Ulum Loram Kulon Jati Kudus, salah satu madrasah Ibtidaiyyah yaang memadukan kurikulum kemenag dengan kurikulum lokal, dan merupakan satu-satunya madrasah yang masih mempertahankan mata pelajaran salafi. Peneliti menggunakan metode kualitatif jenis case study yaitu salah satu jenis penelitian dimana peneliti melakukan eksplorasi secara mendalam terhadap objek penelitian. Data dikumpulkan dengan cara wawancara, observasi dan dokumentasi, selanjutnya data dianalisis dengan cara reduksi, penyajian data, penarikan kesimpulan dan verifikasi. Hasil penelitian menunjukkan bahwa desain penguatan pembelajaran bahasa arab dengan mengkolaborasikan mata pelajaran lokal seperti BTA pada kelas bawah, nahwu dan shorof pada kelas atas. Dengan model yang demikian peserta didik akan mudah memahami materi bahasa Arab, dan mampu menganalisa serta menyajikannya dengan kaidah bahasa yang sesuai.

Kata kunci: Desain penguatan, pembelajaran Bahasa Arab, dan MI NU Miftahul Ulum Kudus 


\section{A. Pendahuluan}

Bahasa Arab adalah bahasa yang digunakan secara aktif oleh sekitar 280 juta penduduk dunia, yang sebagian besar berada di kawasan Timur Tengah dan Afrika Utara. Bahasa Arab juga menjadi bahasa ibu di hampir 25 negara, dan juga telah menjadi salah satu bahasa resmi yang diakui dan dipakai dalam siding-sidang resmi PBB. Di samping itu, bahasa Arab juga tidak bisa dipisahkan dari perkembangan agama Islam, karena Islam itu sendiri pada awalnya lahir dan berkembang di tanah Arab. Seiring dengan penyebaran agama Islam ke seluruh dunia, bahasa Arab juga berkembang dan menyebar ke seluruh dunia, meskipun dengan tingkat intensitas penyebaran berbeda-beda. Di Indonesia, bahasa Arab telah hadir bersamaan dengan kedatangan Islam itu sendiri di Nusantara ini. Bukti-bukti sejarah telah mencatat tentang adanya kitab-kitab berbahasa Arab yang ditemukan pada masa-masa awal kedatangan Islam di Indonesia ini (Munip, 2019).

Saat ini, bahasa Arab telah dipelajari secara akademik di berbagai negara dengan mayoritas penduduk beragama Islam.Dalam dunia luas, mempelajari bahasa Arab bukanlah suatu hal yang di anggap asing. Banyak instansi pendidikan di Indonesia yang telah menjadikan bahasa Arab sebagai salah satu materi yang diajarkan. Hal ini membuktikan bahwa masyarakat kita sudah semakin sadar akan kebutuhan mempelajari bahasa Arab. Bagi umat Islam khususnya, mempelajari bahasa Arab sangat diperlukan dalam rangka mempelajari ajaran Islam yang diturunkan dengan menggunakan bahasa Arab. Tanpa mempelajari bahasa Arab, ilmu pengetahuan dan juga ajaran Islam akan sulit diketahui dan diterapkan dengan baik (Arsyad, 2004).

Bahasa Arab jika dilihat daripenggunaannya di Indonesia, dalam lingkungan dan masyarakat umumnya bahasa Arab adalah bahasa asing, karena bukan merupakan bahasa pergaulan sehari-hari. Halini dapat disaksikan di lembaga pendidikan berbasis Islam mulai dari pendidikan dasar sampai perguruan tinggi. Bahasa Arab diposisikan sebagai bahasa asing, termasuk kedudukannya dalam kurikulum. Hal lain yang dapat dijadikanindikator keasingannya adalah bahasa Arab tidak digunakan sebagai bahasa pengantar pelajaran, tetapi sebagai materi pelajaran

Pembelajaran bahasa Arab tingkat dasar belum berkembang ke arah kemampuan bahasa Arab yang sebenarnya. Kurikulum pendidikan dasar pada sekolah umum pelajaran bahasa Arab belum mendapatkan kedudukan sebagai mata pelajaran yang wajib dipelajari, dan hanya disisipkan pada pelajaran agama. Sementara itu, pada Sekolah dasar yang berciri khas agama Islam seperti Madrasah Ibtidaiyah (MI), bahasa Arab sudah menjadi mata pelajaran 
yanga wajib dipelajari, namun pembelajarannya belum maksimal dalam segi kompetensi dari hasil belajar yang diinginkan, proses pengajarannya pun lebih banyak bersifat pemberian kaidah kaidah bahasa yang sebenarnya belum relevan dengan tingkat usianya serta tidak sesuai dengan teori pembelajaran bahasa pada anak (Tajuddin, 2017)

Pengajaran bahasa ibu atau bahasa pertama lebih mudah karena terjadi secara alamiah melalui kegiatan dengan orang tuanya dan lingkungannya. Berbeda dengan bahasa asing, pengajarannya cenderung lebih sulit karena bahasa tersebut jarang digunakan atau bahkan tidak pernah sebelumnya sehingga penguasaan kosa kata dan struktur kalimatnya tidak dikenal oleh masyarakat itu. Oleh karena itu pengajaran bahasa asing membutuhkan banyak waktu dan latihan yang teratur dan terus menerus sampai bahasa asing tersebut bisa terkondisikan dan terbiasa bagimasyarakat yang mempelajarinya, demikian juga dengan bahasa arab.

Meskipun tidak mudah untuk mengajarkan bahasa Arab kepada anak, namun harus tetap diusahakan, mengingat banyak sekali manfaat yang akan diperoleh dari mempelajari bahasa Arab. Para pengajar akan memiliki suatu tantangan tersendiri dalam mengajarkannya kepada anak. Berbeda dengan bahasa lain, bahasa Arab memiliki struktur dan susunan kata yang cukup sulit sehingga dibutuhkan metode pembelajaran yang dapat memudahkan mengajarkan bahasa Arab pada anak, terlebih untuk tingkat dasar, mulai dari penyesuaian metode dengan materi-materinya, hingga Strategi lembaga pendidikan tingkat dasar dalam menyiasati pembelajaran bahasa Arab agar menjadi mudah difahami para peserta didik. Karena itu kurikulum Bahasa Arab harus lebih mendalam dan meluas sehingga cukup membekali kompetensi literasi peserta didik. Secara konten dan penyajiannya dituntut bagaimana pembelajaran bahasa Arab disajikan dalam sistem yang komunikatif, ekspresif, fungsional, inspiratif, dan menantang, sehingga bahasa Arab dipersepsikan sebagai bahasa yang mudah dan menyenangkan namun tidak terlepas dari konteks budaya ke-Indonesiaan (KMA 183, 2019).

Salah satu lembaga pendididikan tingkat dasar yang memberikan perhatian khusus dalam pembelajaran bahasa Arab adalah MI NU Miftahul Ulum, lembaga setingkat SD ini terletak di desa Loram Kulon kecamatan Jati kabupaten Kudus, yang merupakan satu satunya Madrasah Ibtidaiyyah di kecamatan Jati yang menambah mata pelajaran lokal berbasis salaf dengan fungsinya sebagai materi pelajaran penguat untuk bahasa Arab. Hal ini merupakan bentuk perhatian khusus pihak Madrasah agar para siswa mampu memahami materi bahasa Arab sekaligus menjadi ciri khas dan keunggulan di 
madrasah ini. Artikel ini akan mendeskripsikan desain penguatan pembelajaran bahasa Arab di MI NU Miftahul Ulum Loram Kulon Jati Kudus.

\section{B. Pembahasan}

1. Pembelajaran Bahasa Arab

1) Pengertian Pembelajaran Bahasa Arab

Pembelajaran menurut undang-undang nomor 20 tahun 2003 tentang sistem pendidikan nasional adalah proses interaksi peserta didik dengan pendidik dan sumber belajar pada suatu lingkungan belajar (UU No. 20, 2003) Sedangkanmenurut Miarso yang dikutip oleh Indah Komsiyah mengemukakan bahwa pembelajaran adalah usaha mengelola lingkungan dengan sengaja agar seseorang membentuk diri secara positif dalam kondisi tertentu (Miarso, 2012). Penyelenggaraan pembelajaran merupakan salah satu tugas utama guru. Melalui pembelajaran akan terjadi proses pengembangan moral keagamaan, aktifitas, dan kreatifitaspeserta didik melalui interaksi dan pengalaman belajar. Pembelajaran adalah suatu upaya membelajarkan suatu upaya mengarahkan siswa (Thohirin, 2005).

Sedangkan pengertian bahasa Arab dalam Al-mu'jam al-wasith disebutkan, bahasa adalah suara-suara yang diungkapkan oleh setiap masyarakat untuk menyampaikan maksud-maksud mereka (Musthafa, 2004). Menurut Syaikh Mustafa al-Gulayayni, bahasa Arab adalah kalimat yang dipergunakan bangsa Arab dalam mengutarakanmaksud/tujuan mereka (Al Ghalayaini, 1994).

Pembelajaran bahasa Arab adalah suatu upaya membelajarkan siswa untuk belajar bahasa Arab dengan guru sebagai fasilitatordengan mengorganisasikan berbagai unsur untuk memperoleh tujuan yang ingin dicapaiyaitumenguasi ilmu bahasa dan kemahiran bahasa Arab, seperti memahamimateri-materi bahasa Arab, membuat kalimat dalam bahasa Arab, dan sebagainya. Unsur-unsur yang dimaksud yaitu meliputi guru, siswa, metode, media dan sarana prasarana, serta lingkungan.

Bahasa Arab merupakan suatu mata pelajaran yang diarahkan untuk mendorong, membimbing, mengembangkan, dan membina kemampuan serta menumbuhkan sikap positif terhadap bahasa Arab baik reseptif maupun produktif. Kemampuan reseptif yaitu kemampuan untuk memahami pembicaraan orang lain dan memahami bacaan. Kemampuan produktif yaitu kemampuan menggunakan bahasa sebagai alat komunikasi baik secara lisan maupun tulis. Kemampuan berbahasa Arab serta sikap positif terhadap bahasa Arab tersebut sangat penting dalam membantu 
memahami sumber ajaran Islam yaitu al-Qur'an dan hadis, serta kitabkitab berbahasa Arab yang berkenaan dengan Islam bagi peserta didik (Bukhori, 1993).

\section{2) Karakteristik Pembelajaran Bahasa Arab}

Bahasa Arab sebagai bahasa pengantar untuk memahami ajaran Islam. Dengan Bahasa Arab, ajaran Islam dapat dipahami secara benar dan mendalam dari sumber utamanya yaitu Al-Qur'an dan Hadis serta literaturliteratur pendukungnya yang berbahasa Arab seperti Kitab Tafsir dan Syarah Hadis. Bahasa Arab merupakan mata pelajaran bahasa yang diarahkan untuk mendorong, membimbing, mengembangkan dan membina kemampuan serta menumbuhkan sikap positif terhadap Bahasa Arab, baik reseptif maupun produktif. Kemampuan aktif reseptif yaitu kemampuan untuk memahami pembicaraan orang lain dan memahami bacaan. Kemampuan aktif produktif yaitu kemampuan menggunakan bahasa sebagai alat komunikasi baik secara lisan maupun secara tertulis. Kemampuan berbahasa Arab serta sikap positif terhadap Bahasa Arab tersebut sangat penting dalam membantu memahami sumber ajaran Islam yaitu Al-Qur'an dan Hadis serta kitab-kitab berbahasa Arab yang berkenaan dengan Islam bagi peserta didik. Untuk itu, Bahasa Arab di madrasah dipersiapkan untuk pencapaian kompetensi dasar berbahasa yang mencakup empat keterampilan berbahasa yang diajarkan secara integral, yaitu menyimak (maharatu al- istima'), berbicara (maharatu alkalam), membaca (maharatu al-qira'ah) dan menulis (maharatu alkitabah). Adapun unsur bahasa (bunyi, kata, makna dan tata bahasa) diajarkan secara implisit dalam pengajaran empat keterampilan berbahasa (KMA 183, 2019). Karakteristik pembelajaran Bahasa Arab adalah sebagai berikut:

1) Proses pembelajaran dilaksanakan dengan menggunakan bahasa sasaran (Arab). Dengan pembelajaran menggunakan Bahasa Arab guru diharapkan menjadi model penutur sekaligus juga sebagai media bagi peserta didik untuk mendapatkan kosa kata baru;

2) Menjadikan resource (sumber) yang ada di lingkungan madrasah sebagai sumber pembelajaran; dan

3) Pembelajaran Bahasa Arab yang pertama adalah pembelajaran bahasa lisan, selanjutnya bahasa tulis. Sedangkan urutannya adalah mengajarkan mendengar, diikuti berbicara, membaca dan menulis. (KMA 183, 2019) 
3) Keterampilan Bahasa Arab

Pembelajaran bahasa adalah untuk menguasasi ilmu bahasa dan kemahiran berbahasa Arab, sehingga memperoleh kemahiran berbahasa yang meliputi empat aspek yaitu:

1) Kemahiran Menyimak

Kemahiran menyimak sebagai kemahiran berbahasa yang sifatnya reseptif, menerima informasi dari orang lain (pembicara).

2) Kemahiran Membaca

Kemahiran membaca merupakan kemahiran berbahasa yang sifatnya reseptif, menerima informasi dari orang lain (penulis) di dalam bentuk tulisan. Membaca merupakan perubahan wujud tulisan menjadi wujud makna.

3) Kemahiran Menulis

Kemahiran menulis merupakan kemahiran bahasa yang sifatnya yang menghasilkan atau memberikan informasi kepada orang lain (pembaca) di dalam bentuk tulisan. Menulis merupakan perubahan wujud pikiran atau perasaan menjadi wujud tulisan.

4) Kemahiran Berbicara

Sedangkan kemahiran berbicara merupakan kemahiran yang sifatnya produktif, menghasilkan atau menyampaikan informasi kepada orang lain (penyimak) di dalam bentuk bunyibahasa (tuturan merupakan proses perubahan wujud bunyi bahasa menjadi wujud tuturan (Arsyad, 2003)

\section{4) Fungsi Bahasa Arab}

Bahasa Arab memiliki dua fungsi, pertama sebagai alat komunikasi dan kedua sebagai sarana mempelajari ajaran agama Islam yang tertuang dalam Al-quran dan Hadis serta kitab-kitab lainnya. Menurut pandangan ini pembelajaran Bahasa Arab diarahkan untuk mendorong, membimbing, mengembangkan dan membina kemampuan serta menumbuhkan sikap positif terhadap Bahasa Arab, baik reseptif maupun produktif. Kemampuan itu sangat penting dalam membantu peserta didik untuk memahami ajaran Islam dari sumber aslinya yaitu Al-Qur'an dan Hadis, melalui kitab-kitab klasik berbahasa Arab yang otentik. Dengan demikian, diharapkan peserta didik dapat memahami Agama Islam secara tepat, benar dan mendalam serta mampu mengomunikasikan pemahaman tersebut dengan Bahasa Arab secaralisan maupun tulis. 
5) Tingkatan Pembelajaran Bahasa Arab

Pembelajaran Bahasa Arab memiliki 3 tingkatan, diantaranya:

1) Al-Mubtadiin(Pemula)

Tingkatan ini adalah tingkatan yang paling awal dalam pembelajaran bahasa arab, dan biasanya materi yang paling cocok untuk tingkatan ini adalah: menghafalkan al-Mufradat, percakapan yang sederhana, dan mengarang terarah. Ini biasanya digunakan pada level bawah karena ia mencakup kegiatan mengarang yang dimulai dari merangkai huruf, kemudian kata dan kalimat.

2) Al-Mutawasitin(Menengah)

Ketikasiswa pada tingkatan ini berarti dia sudah mendapatkan beberapa materi tentang bahasa arab, dan tugas seorang guru pada saat itu adalah memberi penguatan terhadap materi-materi yang sudah didapatkan oleh siswa, sehingga bisa mahir dalam materi tersebut .

3) Al-Mutaqadimin(Mahir)

Pada tingkatan ini siswa sudah mulai mahir terhadap materi-materi berbahasa arab dan materi yang sesuai bagi siswa yang sudah pada tingkatan ini adalah mengarang bebas. Ini biasanya digunakan pada level tingkat tinggi karena disitu kentrampilan, kreatifitas dari seorang penulis sangat diandalkan (Ainin, 2006)

6) Unsur Pembelajaran Bahasa Arab

Dalam pembelajaran Bahasa Arab ada 3 unsur yang wajib diketahui, diantaranya:

1) Al-Aswat (bunyi)

Dalam pembelajaran bahasa, penguasaan terhadap bunyi menjadi sangat penting. Tujuan pembelajaran bunyi secara umum meliputi penguasaan seluruh sistem bunyi baik dalam bentuk mengenal dan memahami bunyi secara reseptif, maupun dalam bentuk melafalkan dan menggunakan bunyi bahasa secara aktif produktif. Selain dalam bentuk konsonan dan vokal, sistem bunyi meliputi tinggi rendahnya suara (al-Thul), tekanan kata dan kalimat (al-Nabr), intonasi (alTanghim), dan sebagainya

2) Al-Mufradat (Kosa Kata)

Penyampaian pesan bahasa menuntut penggunanya untuk bisa memilih kosakata yang tepat dan sesuai agar dapat mengungkapkan makna yang dikehendaki. Pemahaman yang tepat terhadap pesan yang disampaikan melalui bahasa banyak ditentukan oleh pemahaman dan penggunaan 
yang tepat terhadap kosakata yang digunakan dalam percakapan tersebut.

3) Al-Qawa'id (Tata Bahasa)

Al-Qawa'idmerupakan salah satu komponen bahasa yang penting dan tidak terpisahkan berkaitan dengan penataan kata dalam merangkai kata-kata. Selain itu, tata bahasa juga berkaitan dengan perubahan bentuk kata dalam bahasa Arab. Tujuan pembelajaran tata bahasa secara garis besar meliputi pemahaman dan penggunaan pembentukan kata, frasa dan kalimat (Rosyidi, 2009).

2. Metode Penelitian

Artikel ini menggunakan metode kualitatif jenis case study yaitu salah satu jenis penelitian dimana peneliti melakukan eksplorasi secara mendalam terhadap program, kejadian, proses, aktivitas, terhadap satu atau lebih orang, suatu kasus terikat oleh waktu dan aktivitas (Sugiono, 2012).Dalam artikel ini peneliti mengkaji secara mendalam bagaimana desain penguatan pembelajaran bahasa Arab di MI NU Miftahul Ulum Loram Kulon Jati Kudus. Peneliti melakukan pengumpulan data secara mendetail dengan menggunakan berbagai prosedur pengumpulan data yang berkesinambunganmulai dari observasi, wawancara, dan dokumentasi. Data yang diperoleh kemudian dianalisis dengan cara reduksi data, penyajian data, penarikan kesimpulan dan verifikasi. (Sugiono, 2012)

3. Potret Bahasa Arab di Madrasah Ibtidaiyyah

a. Tujuan Pembelajaran Bahasa Arab di MI

1) Mengembangkan kemampuan berkomunikasi dalam bahasa Arab, baik lisan maupun tulis, yang mencakup empat kecakapan berbahasa, yakni menyimak (istima'), berbicara (kalam), membaca (qira'ah), dan menulis (kitabah).

2) Menumbuhkan kesadaran tentang pentingnya bahasa Arab sebagai salah satu bahasa asing untuk menjadi alat utama belajar, khususnya dalam mengkaji sumbersumber ajaran Islam dan alat komunikasi dalam pergaulan internasional.

3) Mengembangkan pemahaman tentang saling keterkaitanantara bahasa dan budaya serta memperluas cakrawala budaya. Dengan demikian, peserta didik diharapkan memiliki kompetensi bahasa 
yang cakup gramatika, wacana, strategi, sosiologi dan budaya. (KMA 183, 2019)

b. Ruang Lingkup Materi Pelajaran Bahasa Arab di MI

Ruang lingkup Materi Bahasa Arab di Madrasah Ibtidaiyyah terdiri dari tema-tema tentang perkenalan, peralatan madrasah, pekerjaan, alamat, keluarga, anggota badan, di rumah, di kebun, di Madrasah, di laboratorium, di perpustakaan, di kantin, jam, kegiatan sehari-hari, pekerjaan, rumah, dan rekreasi (KMA 183, 2019).Secara rinci materi bahasa Arab di Madrasah Ibtidaiyyah dijabarkan paadaa tabel di bawah ini:

Tabel Persebaran Materi Bahasa Arab di MI

\begin{tabular}{|c|c|c|c|}
\hline Kelas & Tema Semester 1 & Tema Semester 2 & Struktur Kalimat \\
\hline 1 & $\begin{array}{l}\text { Ta'aruf, } \\
\text { Hiwayati }\end{array}$ & $\begin{array}{l}\text { Baiti, asmaul } \\
\text { fawakih, alwan }\end{array}$ & $\begin{array}{l}\text { Isim Isyarah (hadza- } \\
\text { hadzihi) }\end{array}$ \\
\hline 2 & $\begin{array}{l}\text { Afradul madrasah, } \\
\text { Al adawat Al } \\
\text { madrasiyyah, } \\
\text { alziyul madrasiy }\end{array}$ & $\begin{array}{l}\text { Wasailul } \\
\text { Muwashalat, } \\
\text { Astastul Manzil, Al } \\
\text { Manadhir } \\
\text { Attabi'iyyah, }\end{array}$ & $\begin{array}{l}\text { Isim Isyarah (hadza- } \\
\text { hadzihi) }\end{array}$ \\
\hline 3 & $\begin{array}{lr}\text { Al Mawad } & \text { Al } \\
\text { dirasiyyah, Asma'ul } \\
\text { Hayawanat, } \\
\text { amrodl }\end{array}$ & $\begin{array}{l}\text { Arriyadloh, } \\
\text { Ashdiqa'i, } \\
\text { hadiqah }\end{array}$ & $\begin{array}{l}\text { Isim Isyarah (hadza- } \\
\text { hadzihi, dzalika- } \\
\text { tilka) }\end{array}$ \\
\hline 4 & $\begin{array}{l}\text { Al unwan, } \\
\text { mihnah, amali }\end{array}$ & $\begin{array}{lr}\text { Afradul } & \text { Usrah, Fil } \\
\text { Baiti, } & \text { Uhibbu } \\
\text { Indonesia } & \\
\end{array}$ & $\begin{array}{lr}\text { Isim } & \text { Isyarah-Dlomir } \\
\text { Munfashil, } & \text { Isim } \\
\text { isyarah-Isim } & \text { mufrad }\end{array}$ \\
\hline 5 & $\begin{array}{l}\text { A'dloul Jismi, } \quad A l \\
\text { Mihnah, Hadiqatul } \\
\text { Hayawanat, }\end{array}$ & $\begin{array}{lr}\text { Fil } & \text { ghurfatul } \\
\text { Istiqbal } & \text { wa } \\
\text { ghurfatul } & \\
\text { mudzakarah, } & \text { fil } \\
\text { ma'mal } & \text { wa } \\
\text { maktabul } & \\
\text { madrasah, } & \text { fil } \\
\text { maqshaf } & \end{array}$ & $\begin{array}{l}\text { Isim Isyarah lil } \\
\text { mufrad+isim+shifat, } \\
\text { Al Mubtada' wal } \\
\text { Khobar, Mubtada' } \\
\text { mu'akhor dan } \\
\text { khobar muqaddam }\end{array}$ \\
\hline 6 & $\begin{array}{l}\text { Assa'ah, } \\
\text { Lughah }\end{array}$ & $\begin{array}{l}\text { Al 'uthlah, } \\
\text { nuzhatu }\end{array}$ & $\begin{array}{l}\text { Fi'il Mudlori', Fi'il } \\
\text { Amar, Fiil madhi, }\end{array}$ \\
\hline
\end{tabular}




\begin{tabular}{l|l|l|l}
\hline & $\begin{array}{l}\text { 'arabiyyah, Uhibbul } \\
\text { Ansyithah }\end{array}$ & & \\
\hline
\end{tabular}

Dalam materi-materi tersebut terdapat fungsi komunikatif yaitu: memberi salam, menjawab salammenanyakan nama dan kabar, meminta dan memberi informasi tentang diri dan anggota keuarga, meminta dan memberi informasi tentang nomor rumah, meminta dan memberi informasi nama buah, presensi kehadiran siswa di kelas, instruksi harian di kelas, meminta informasi nama alat transportasi, deskripsi pemandangan yang di lihat, memilih olah raga yang disukai, nama tanaman, meminta alamat seseorang, memilih profesi, mengungkapkan harapan, struktur anggota keluarga, deskripsi aktifitas di rumah, mengekspresikan rasa cinta agama, mesdeskripsikanaktifitas di lab dan perpustakaan (meminjam, dan mengembalikan buku dll), meminta informasi jenis makanan di kantin (menu), meminta informasi tentang waktu, mengekspresikan rasa cinta bahasa arab, perintah melakukan sesuatu, mendeskripsikan pilihan aktifitas di hari libur, mendeskripsikan suasana di tempat rekreasi.

4. Desain Penguatan Pembelajaran Bahasa Arab di MI NU Miftahul Ulum Loram Kulon Jati Kudus

Pembelajaran bahasa Arab untuk jenjang MI paling tidak dapat mempersiapkan murid agar mampu mengidentifikasi bunyi huruf dan kata serta menemukan makna kata atau kalimat dari wacana lisan secara sederhana. Secara sederhana, berarti murid mendengar bacaan, ujaran, kata, atau kalimat, kemudian mencerna dan mengolahnya dalam otak, menemukan artinya, kemudian memahami pesan dari yang didengarkan Bahasa arab sebagai bahasa asing tentunya mempunyai perhatian khusus bagi setiap lembaga pendidikan, apalagi lembaga tingkat dasar seperti madrasah ibtidaiyyah. Termasuk di MI NU Miftahul Ulum Loram Kulon Jati Kudus, perhatian para pemangku madrasah terhaadap bahasa Al Qur'an ini sangat banyak, lembaga ini merupakan satu satunya di kecamatan Jati yang tetap mempertahankan materi materi salafi seperti nahwu, sharaf, ahlaq salaf, tauhid salaf, tahfid dan baca tulis al Qur'an. Setiap mata pelajaran yang masuk dalam kategori kurikulum lokal di MI ini masing-masing mempunyai peranan untuk memberikan penguatan terhadap mata pelajaran lain, termasuk memberikan penguatan terhadap mata pelajaran bahasa arab yang masuk dalam kategori kurikulum Kemenag. 
Di madrasah ini mata pelajaran pada kurikulum lokal yang memberikan penguatan terhadap mata pelajaran bahasa Arab adalah

a. BTA (Baca Tulis Al-Qur'an)

Mata Pelajaran ini diajarkan di kelas 1,2, dan 3. Meskipun secara tekstual nama mata pelajaran berbunyi baca tulis Al Qur'an atau berkaitan dengan Al Qur'an, namun tulisan al Qur'an yang menggunaakan bahasa arab tentunya mata pelajaran ini memberikan pengaruh terhadap pembelajaran bahasa arab. Dalam buku pegangan BTA beberapa materi yang sangat terkait erat dengan bahasa arab diantaranya;

1) Pada kelas satu, fokus materinya mengenalkan huruf dan tanda baca melalui kata, membaca kata dan kalimat sederhana, pada materi ini peserta didik dikenalkan bagaimana cara menulis dan membaca huruf arab, kata serta kalimat arab. Hal ini sesuai dengan kompetensi dasar bahasa arab kelas satu yaitu memahami bunyi, kata dari teks sederhana, menganalisa unsur kebahasaannya dan menyajikan analisis bunyi kata dan makna dari teks sederhana tersebut dengan memperhatikan kaidah penulisan huruf sambung.

2) Pada kelas dua, materi yang dipelajari masih terkait dengan membaca dan menulis kata dan kalimat sederhana, namun di kelas dua ini ditambahkan kaidah atau tata caraa membaca dan menulis dengan tanda baca/ huruf mad (alif, ya', wau). Ini tentunya memudahkan peserta didik daalam mempraktekkan bunyi kata kosa kata dalam bahasa arab, terdapat banyak sekali kosa kata terkait tema yang diaajarkan di krelas dua ini yang menggunakan tanda baca huruf mad, misalnya pada tema al adawat al madrasiyyah, atsatsul manzil dan al manadzir attabi'iyyah.

3) Materi kelas tiga fokus pada tata cara membaca huruf yang dibaca mati baik ditengah kata maupun ketika diwaqafkan dan tata cara melafalkan huruf yang ditasydid. Kaitannya dengan penguatan pembelajaran bahasa arab masih pada taraf baagaimana peserta didik dapat menulis dan membaca kata atau kalimat berbahasa arab dengan baik dan benar.

Pada dasarnya penguatan pembelajaran bahasa arab dengan mata pelajaran BTA adalah pada tataran bagaimana siswa mampu melafalkan kosa kata bahasa arab dengan benar sesuai kaidah pelafalan huruf hijaiyyah dan tanda bacanya serta mampu menyajikan 
atau menulis kata dengan kaidah yang sesuai seperti kaidah penyambungan huruf hijaiyyah dalam kata bahasa Arab. Nah hal ini tentunya memberikan penguatan pada pembelajaran bahasa Arab untuk kategori kelas bawah (1,2 dan 3) dalam memahami unsur kebahasaan mulai dari bunyi, kata dan makna dari teks sederhana dalam bahasa Arab.

b. Nahwu

Berbeda dengan BTA yang diajarkan di kelas bawah, mata pelajran ini diberikan di kelas atas yaitu kelas 4,5 dan 6. Buku ajar yang digunakan berupa kitab berbahasa arab dan terjemahan dalam bahasa jawa, namun biasanya guru memberikan keterangan tambahan dengan menggunakan bahasa indonesia untuk memudahkan siswa dalam memahami materi. Berikut ini sebaran materi nahwu sebagai penguatan pembelajaaran Bahasa Arab pada setiap kelas:

1) Pembelajaran nahwu kelas 4 menggunakan buku modul berbahasa jawa karya K.H. Yahya Arif dengan judul “ Nahwu Jawan” dalam modul ini materinya msih bersifat dasar dan sesuai dengan tingkat pemahaman anak yang baru dikenalkan dengan mata pelajaran nahwu. Materi-materi yang berkaitan dengan Mata pelajaran bahasa arab dan memberikan penguatan terhadap mapel tersebut diantaranya siswa dikenalkan dengan bentuk kalimat isim dan fi'il serta bagaimana perbedaannya, setelah siswa memahami isim dan fi'il, mereka dikenalkan dengan bentuk isim mufrad isim tasniyyah dan isim jama'. Materi materi tersebut tentunya sangat membantu memahami materi dalam bahasa arab khususnya di kelas 4 yakni memahami dan menganalisa kata dalam teks sederhana secara lisan maupun tulisan dengan memperhatikan struktur Isim isyarah dan isim mufrad. Dengan adanya materi nahwu yang diberikan kepada siswa tentunya sangat membantu siswa dalam memahami materi bahasa arab.

2) Pada kelas 5 kitab yang digunakan adalah al kifaayah ala tarjamati maatan jurumiyyah, buku ini terdiri dari matan jurumiyyah yang berbahasa arab dan terjemahannya dengan menggunakan bahasa Jawa, sama dengan kelas 4, guru pun memberikan keteragan tambahan dengan menggunakan bahasa Indonesia. Materi dalam buku ini yang memberikan penguatan terhadap pembelajaran bahasa Arab kelas 5 diantaranya siswa dikenalkan dengan ciri-ciri 
kalimat isim , Fi'il, dan huruf serta bentuk kalimat isim ketika rafa' dan nashab. srtruktur yang dipelajari dalam bahasa arab kelas 5 lebih kompleks yaitu isim isyarah muannas, isim mufrodah dan isim sifat, tentunya dengan bantuan nahwu siswa sudah memahami bentuk bentuk kalimat isim yang mufrad mudzakkar dan mufradah mu'annatsah serta perbedaannya karena pada bahasa arab mereka akan menganalisa struktur muannas dan mudzakkar dan menyesuaikannya dengan bentuk isim isyarah yang digunakan. Pada semester dua, siawa akan mempelajari struktur mubtada' khobar, khobar muqaddam dan mubtada' muakkhar. Dalam strktur ini tentunya berbentuk kalimat isim bahkan dalam struktur khobar muqaddam terdapat huruf jer dalam kerangka penyusunannya, nah dengan hadirnya nahwu yang sudah memperkenalkan siswa tentang materi kalimat huruf, karakteristik dan contohnya akan memudahkan siswa dalam menyajikan dan memahami teks sederhana dalam mata pelajaran bahasa Arab

3) Kitab nahwu yang digunakan di kelas 6 sama dengan kelas 5, adapun materi yang diajarkan melanjutkan kelas 5. Pada kelas 6 struktur kalimat yang dipelajari adalah kalimat sederhana yang didalamnya terdapat kata kerja baik berupa fi'il madli, mudlori' dan amar. Materi ini sudah disajikan terlebih dahulu dalam mata pelajaran nahwu tentang babul 'af'ali, ciri-ciri kalimat fi'il, dan i'rab fi'il mudlorik. Dalam materi ini siswa sudah memahami baagaimana bentuk masing masing kalimat fi'il baik madli, mudlari' maupun amar bahkan siswa sudah mengetahui i'rab atau perubahan fi'il mudlari' sesuai dengan kedudukannya.

Kehadiran mata pelajaran nahwu mulai kelas 4 sampai 6 memberikan pengaruh terhadap pemahaman siswa terhadap materi yang berkaitan dengan bahasa arab pada masing masing kelas. Materi nahwu yang diberikan secara bertahap terdsebut tentunya memberikan penguataan yang berkesinambungan terhadap pembelajaran bahasa Arab, terlebih dalam memahami teks sederhana dengan menggunakan struktur tata bahasa pada setiap jenjang.

c. Shorof

Sama halnya dengan nahwu, keberadaan ilmu sharaf sebagai ilmu alat dalam bahasa arab menjadikanata pelajaaran ini menjadi mata pelajaran khas sebagai penguat pemnelajaran bahaasa arab. Di MI NU 
Miftahul Ulum mata pelajaran ini menggunakan Al amtsilah at tashrifiyyah karya Syeh Muhammad Ma'shum Bin Ali. Buku ini sangat masyhur dan biasa dipakai untuk mempelajari ilmu sharaf. Mata pelajaran ini dipelajari di kelas 4, 5, dan 6 dan dipelajari secara berjenjang disesuaikan dengan perkembangan peserta didik.

Pada kelas 4 peserta didik dilenalkan terlebih dahulu dengan macam-macam bentuk kalimat fi'il, bina' dan contoh-contohnya, setelah itu masuk pada materi yang pertama yaitu fi'il tsulasi mujarrad pengertian dan pembagiannya. Pada tahap awal ini siswa hanya menghaflkan satu bab saja, namun setiap satu kalimat fi'il dihafalkan tashrif istilahinya beserta shighat dan maknanya. Di kelas 5 masih dengan kitab yang sama, materi dilanjutkan dengan mengulas kembali fi'il tsulasi mujarrad, dan fi'il ruba'i mujarradpembagiannya serta contohnya. Siswa diharuskan hafal maateri setiap bab, mulai bab satu sampai bab 6, sama seperti kelas 4, di kelas 5 ini siswa juga menghafalkan tashrif istilahinya beserta shighot dan maknanya, biasanya setiap bab diberikan contoh 3-4 kalimat fi'il. Sedangkan materi sharaf yang diajarkan di kelas 6 adalah fi'il tsulasi mazid biharfin, mazid biharfaini, dan mazid bistalastati ahrufin. Sama halnya di kelas 4 dan 5, pada tingkat ini siswa juga menghafalkan bentuk wazannya kemudian contoh-contohnya beserta shigot dan maknanya.

Dengan mempelajari sharaf mulai kelas 4-6 siswa tentunya dapat memahami bentuk-bentuk kalimat fi'il mulai dari fi'il madli, mudlori' dan amar beserta perubahannya. Materi ini juga terdapat pada bahasa arab. Hal tersebut akan lebih membantu siswa agar lebih mudah memahami pola struktur kalimat fi'il dalam telks sederhana, siswa juga mampu menganalisa perubahan bentuk yang terjadi pada setiap kalimat fi'il, mereka juga dapat menyajikan kalimat sederhana dengan penggunaan kata kerja yang sesuai dengan waktu yang dibutuhkan, seperti masa lampau dengan fi'il madli, saat ini atau akan dilakukan menggunakan fi'il mudlori', dan amar untuk kalimat perintah.

Desain penguatan pembelajaaran bahasa arab di MI NU Miftahul Ulum Jati Kudus secara sederhana tergambar dalam bagan di bawah ini: 
Desain Penguatan Pembelajaran Bahasa Arab

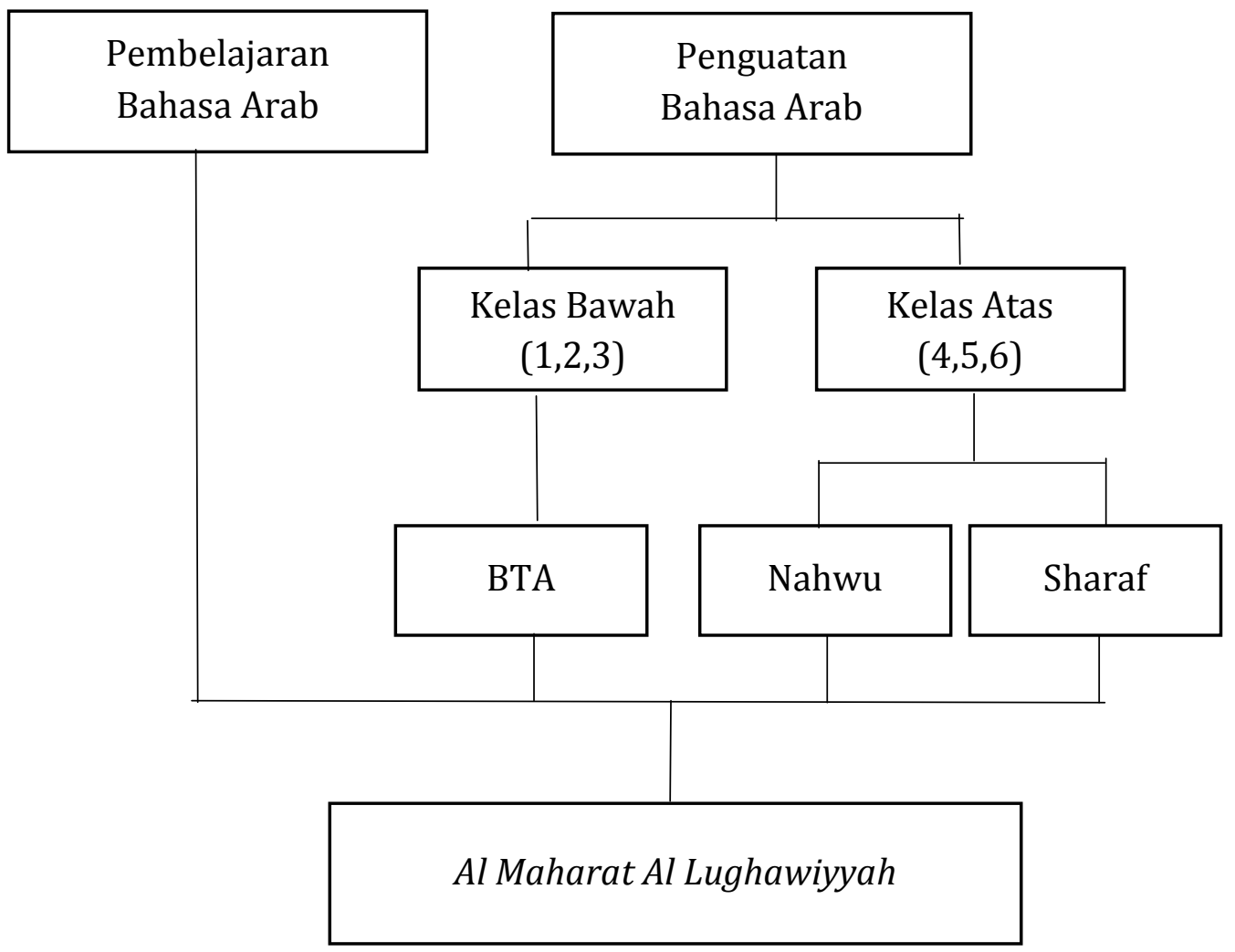

Penguatan pembelajaran bahasa Arab dapat dibedakandalam dua kelompok yaitu kelas bawah dan kelas atas. Pada kelas 1,2, dan 3.Kemampuan berbahasa Arab dapat diintegrasikan dengan keterampilan membaca Alquran. Contoh-contoh yang disajikan dapat menggunakan kata atau kalimat dari Alquran, hal ini merupakan peranan materi pendukung seperti mata pelaajaran BTA sebagai materi penguatan untuk bahasa arab kelas bawah. Sedangkan pada tingkatan kelas atas, yaitu kelas 4,5, dan 6 mulai dikenalkan struktur kalimat yang dapat membantu untuk menggunakan kata dan kalimat itu dalam kegiatan percakapan sehari-hari. Selain itu dengan materi nahwu dan sharaf pada kelas atas memungkinkan siswa untuk dapat menyajikan kalimat sederhana sesuai dengan kaidah tata bahasa arab.Selain itu porsi mata pelajaran bahasa arab pada masing masing kelas yang diberikan hanya 2x jam pelajaran setiap minggu jika tidak dibantu dengan mata pelajaran lain yang posisinya sebagai penguat tentunya hasilnya kurang maksimal. 


\section{Kesimpulan}

Bahasa Arab merupakan mata pelajaran yang dipelajari oleh lembagalembaga pendidikan di Indonesia, khususnya lembaaga berbasis Islam, mulai tingkat dasar hingga perguruan tinggi. Mempelajarinya membutuhkan treatmen khusus agar materi ini dapat dipahami oleh peserta didik. Salah satunya adalah dengan memberikan mata pelajaran lain yang berfungsi sebagai penguatan pembelajaran bahasa Arab. MI NU Miftahul Ulum sebagai lembaga pendidikan dasar mempunyai desain penguatan pembelajaran bahasa arab dengan mata pelajaran lokal yaitu BTA untuk kelas bawah tujuannya adaalah agar siswa mampu melafalkan kosa kata, bunyi dan teks sederhana serta menyajikannya dengan kaidah penulisan arab yang benar. Kemudian nahwu dan sharaf untuk kelas atas. Dengan adanya materi ini siswa mampu memahami struktur kalimat dalam bahasa arab dan menyajikannya dengan pola kalimat yang sesuai. 


\section{Daftar Pustaka}

Ainin, M. dkk, 2006. Evaluasi Dalam Pembelajaran Bahasa Arab. Malang: Myskat.

Al-GulayaIni. Mustafa. 1994. Jami' al-Durus al-'Arabiyyah, Jus I. Cet. XXX, Beirut: alMaktabah al-Asriyyah.

Arsyad, Azhar. 2003. Bahasa Arab dan Metode Pengajarannya, Surabaya: Pustaka Pelajar.

2004. Bahasa Arab dan Metode Pengajarannya. Yogyakarta: Pustaka Pelajar.

Bukhori. 1993.Teknik-Teknik Data Evaluasi Pendidikan, Bandung: Jemars.

Keputusan Menteri Agama No. 183 Tahun 2019 tentang Kurikulum PAI dan Bahasa Arab pada Madrasah. Direktorat KSKK Madrasah Dirjen Pendidikan Islam Kemenag RI

Miarso. 2012. Belajar dan Pembelajaran, Yogyakarta: Teras.

Munip, Abdul. 2019. Tantangan dan Prospek Studi Bahasa Arab di Indonesia, al Mahāra Jurnal Pendidikan Bahasa Arab, Vol. 5, No. 2, Desember 2019.

Mustafa, Ibrahimdkk 2004.Al-mu'jam al-wasit. . Cetakan: ke 4. Istanbul: AlMaktaba al-Islamiyah

Rosyidi, Abdul Wahab. 2009. Media Pembelajaran Bahasa Arab, Malang: UIN Malang Press.

Sugiono. 2012. Metode penelitian kuantitatif, kualitatif, dan kombinasi. Bandung, Alfabeta.

Tajuddin, Shafruddin. 2017. Pengembangan Model Pembelajaran Bahasa Arab Tingkat Sekolah Dasar Untuk Meningkatkan Kemampuan Berbahasa Arab Siswa, Jurnal Parameter Volume 29 No. 2 Tahun 2017

Thohirin. 2005. Psikologi Pembelajaran PAI. Jakarta: Grafindo Persada.

Undang-Undang Republik Indonesia Nomor 20 Tahun 2003 tentang Sistem Pendidikan Nasional. 